\title{
Bacteroides oulorum sp. nov., a Nonpigmented Saccharolytic Species from the Oral Cavity
}

\author{
HAROUN N. SHAH, ${ }^{1 *}$ MATTHEW D. COLLINS,${ }^{2}$ JUNKO WATABE, ${ }^{3}$ AND TOMOTARI MITSUOKA ${ }^{3,4}$ \\ Department of Oral Microbiology, London Hospital Medical College, London El 2AD, United Kingdom ${ }^{1}$; Department of \\ Microbiology, National Institute for Research in Dairying, Shinfield, Reading RG2 9AT, United Kingdom ${ }^{2} ;$ The Institute \\ of Physical and Chemical Research, Wako, Saitama 351, Japan ${ }^{3}$; and Department of Biomedical Science, Faculty of \\ Agriculture, University of Tokyo, Bunkyo-ku, Tokyo 113, Japan ${ }^{4}$
}

\begin{abstract}
Bacteroides oulorum, a new nonpigmented, saccharolytic species from oral cavities, is described. This species differs both biochemically and chemically from related taxa, such as Bacteroides oralis, Bacteroides buccalis, Bacteroides denticola, Bacteroides veroralis, and Bacteroides pentosaceus. The major fermentation products in glucose broth are acetate and succinate. In common with other members of the genus Bacteroides, all strains contain malate dehydrogenase and glutamate dehydrogenase, but they differ from some species, such as Bacteroides fragilis, in lacking glucose-6-phosphate dehydrogenase and 6-phosphogluconate dehydrogenase. The long-chain fatty acids are predominantly of the straight-chain saturated, iso- and anteiso-methyl branched types, with 12-methyltetradecanoic acid constituting the major acid. Strains of $B$. oulorum can be clearly distinguished from other oral Bacteroides species by the presence of major amounts of unsaturated menaquinones with 10 isoprene units. The deoxyribonucleic acid base composition of $B$. oulorum is 45 to 46 mol\% guanine plus cytosine. The type strain is WPH 179 (= NCTC 11871).
\end{abstract}

Until recently, the taxonomy of nonpigmented saccharolytic oral Bacteroides has been unsatisfactory $(5,6,19,24)$. Chemotaxonomic techniques, such as deoxyribonucleic acid (DNA) base composition, DNA-DNA homology, enzymatic, and lipid analyses, have confirmed the heterogeneity of this large group of organisms and have led to the recognition of several new species, including Bacteroides buccae, Bacteroides oris (8), Bacteroides buccalis, Bacteroides denticola, Bacteroides pentosaceus (19), Bacteroides capillus (11), and Bacteroides veroralis (24). In the course of a systematic study of nonpigmented, saccharolytic Bacteroides strains from gingival plaque, three isolates were found to be phenotypically distinct from Bacteroides oralis and related species (Shah, Mitsuoka, Watabe, and Collins. Abstr. Br. Soc. Dent. Res. 1984, abstr. no. 237). In this paper we describe the results of a comparative biochemical and chemical study of these isolates and other oral Bacteroides species. Our results indicate that the three strains studied are members of the genus Bacteroides since they are gramnegative, obligately anaerobic, nonsporeforming rod-shaped organisms which produce major amounts of acetic and succinic acids as the end products of glucose metabolism. Furthermore, on the basis of biochemical, chemical, and genetic data these three strains represent a distinct species, for which the name Bacteroides oulorum $\mathrm{sp}$. nov. is proposed.

\section{MATERIALS AND METHODS}

Strains. The test strains are listed in Table 1. B. oulorum WPH $179^{\mathrm{T}}(\mathrm{T}=$ type strain) was isolated from subgingival plaque by W. P. Holbrook, and strains RS14 and RS20 were isolated from the gingival crevices of two individuals (London Hospital, London, United Kingdom).

Physiological reactions and acid end product analysis. All strains were grown and maintained by weekly subculture on modified Eggerth-Gagnon agar (14), horse blood agar plates, or BM medium, as described previously (23). Physiological

\footnotetext{
* Corresponding author.
}

reactions were determined with an API $20 \mathrm{~A}$ anaerobic test kit (API, Montalien-Varcien, France). The pH of each well was recorded with a micro $\mathrm{pH}$ electrode (Pye Unicam, Cambridge, United Kingdom) after $48 \mathrm{~h}$ of growth (10). Cells grown in BM or peptone-yeast extract-glucose medium were analyzed for their metabolic end products by gas-liquid chromatography as described previously $(1,2)$.

Dehydrogenase activity and electrophoresis. Malate dehydrogenase and glutamate dehydrogenase activities were measured in cell-free extracts of all strains by a spectrophotometric method (21), and the relative electrophoretic mobilities of these enzymes were determined both on Cellogel strips (Reeve Angel Scientific Ltd.) (22) and by polyacrylamide gel electrophoresis $(15,16,24)$. Glucose-6-phosphate dehydrogenase and 6-phosphogluconate dehydrogenase activities were tested by a spectrophotometric method similar to the method described above (22).

Extractions and analysis of fatty acid methyl esters. Dry cells $(50 \mathrm{mg})$ were degraded by acid methanolysis and examined by thin-layer chromatography and gas-liquid chromatography as described previously (4).

Analysis of isoprenoid quinones. Isoprenoid quinones were extracted from dry cells $(100 \mathrm{mg})$ as described previously (3). Purified quinones were analyzed by reverse-phase partition high-performance liquid chromatography, using a chromatograph (Laboratory Data Control) fitted with a Spherisorb ODS $(5 \mu)$ column and methanol-1-chlorobutane $(100: 20, \mathrm{vol} / \mathrm{vol})$ as the eluent $(1.5 \mathrm{ml} / \mathrm{min})$. Quinones were monitored at $270 \mathrm{~nm}$, and quantitation was achieved by using a model 308 computer integrator (Laboratory Data Control). Mass spectra of the quinones were recorded with a model AE1 MS9 instrument by using a direct insertion probe, an ionizing voltage of $70 \mathrm{eV}$, and a temperature range of 180 to $220^{\circ} \mathrm{C}$.

DNA base composition. DNA was isolated and purified by previously described methods $(12,17)$. The guanine-pluscytosine $(G+C)$ contents of DNA preparations were estimated by thermal denaturation (13), using either an auto- 
TABLE 1. Physiological and biochemical characteristics of $B$. oulorum and related taxa

\begin{tabular}{|c|c|c|c|c|c|c|c|c|}
\hline \multirow[b]{2}{*}{ Strain $(\mathbf{s})^{a}$} & \multicolumn{8}{|c|}{ Acid produced ${ }^{b}$ from: } \\
\hline & $\begin{array}{c}\text { Arabi- } \\
\text { nose }\end{array}$ & $\begin{array}{l}\text { Cello- } \\
\text { biose }\end{array}$ & $\begin{array}{l}\text { Glyc- } \\
\text { erol }\end{array}$ & $\begin{array}{l}\text { Meli- } \\
\text { biose }\end{array}$ & $\begin{array}{l}\text { Rham- } \\
\text { nose }\end{array}$ & $\begin{array}{l}\text { Sali- } \\
\text { cin }\end{array}$ & Xylan & Xylose \\
\hline $\begin{array}{l}\text { B. denticola } \\
\text { NCDO } \\
2352^{\mathrm{T}} \text { and } \\
1221\end{array}$ & - & - & + & - & - & - & - & - \\
\hline $\begin{array}{l}\text { B. buccalis } \\
\text { NCDO } \\
2354^{\mathrm{T}} \text { and } \\
\text { VPI } \\
\text { 8906D }\end{array}$ & - & + & - & + & - & + & - & - \\
\hline $\begin{array}{l}\text { B. oralis } \\
\text { ATCC } \\
33269^{\mathrm{T}}\end{array}$ & - & + & - & + & - & + & - & - \\
\hline $\begin{array}{l}\text { B. veroralis } \\
\text { ATCC } \\
33779^{\mathrm{T}}\end{array}$ & - & + & - & $w+$ & - & - & + & - \\
\hline $\begin{array}{l}\text { B. pentosa- } \\
\text { ceus } \\
\text { NCDO } \\
2353^{\mathrm{T}}, \mathrm{J} 1 \text {, } \\
\text { and } \mathrm{WPH} \\
61\end{array}$ & + & + & - & + & + & + & + & + \\
\hline $\begin{array}{l}\text { B. oulorum } \\
\text { WPH } \\
179^{\mathrm{T}}, \\
\text { RS14, } \\
\text { and RS20 }\end{array}$ & - & - & - & $w+$ & - & - & - & - \\
\hline
\end{tabular}

${ }^{a}$ All strains produced acid from glucose, lactose, maltose, mannose, raffinose, and sucrose. All strains failed to produce acid from mannitol, melezitose, sorbitol, and trehalose. All strains hydrolyzed esculin and were indole negative. All strains failed to hydrolyze gelatin. Information in part from references 7,19 , and 24 .

${ }^{b}+$, Positive reaction; - , negative reaction; $\mathrm{w}+$, weak reaction.

matic recording spectrophotometer (Komatsu Electronics, Tokyo, Japan) or a model 240 spectrophotometer (Gilford Instrument Laboratories, Inc., Oberlin, Ohio) equipped with a Gilford model 2527 thermoprogrammer at heating rates of 0.5 and $1^{\circ} \mathrm{C} / \mathrm{min}$; calf thymus DNA or Escherichia coli strain B DNA was used as a reference.

DNA-DNA reassociation. DNA-DNA reassociation experiments were performed as described previously by using the S1 nuclease procedure $(9,21,24)$. S1 nuclease digestion was performed with $0.5 \mathrm{U}$ of $\mathrm{S} 1$ nuclease (Seikagaku, Kogyo Co., Tokyo, Japan). After incubation for $15 \mathrm{~min}$ at $37^{\circ} \mathrm{C}$, an equal volume of $10 \%$ trichloroacetic acid was added to each tube. The tubes were cooled to $4^{\circ} \mathrm{C}$ for at least $1 \mathrm{~h}$, and the precipitates were collected on nitrocellulose membrane filters (type HA; Millipore Corp., Bedford, Mass.). The membranes were dried, and the radioactivity was measured.

\section{RESULTS AND DISCUSSION}

The results of the biochemical tests are shown in Table 1. These results confirmed the close biochemical relatedness of the taxa tested. $B$. oulorum most closely resembled $B$. denticola but could be distinguished from the latter by its inability to ferment glycerol. B. oulorum also differed from $B$. denticola in weakly fermenting melibiose. B. buccalis and $B$. oralis were readily distinguished from $B$. oulorum in fermenting cellobiose and salicin, whereas $B$. pentosaceus differed from all of the other species examined in fermenting the pentose sugars arabinose and xylose (Table 1).

All of the strains examined produced major levels of acetic and succinic acids from peptone-yeast extract-glucose or $\mathrm{BM}$ medium. In addition, the strains of $B$. buccalis produced isovaleric acid, as reported previously (24). All taxa produced high levels of malate dehydrogenase and glutamate dehydrogenase ( $>200 \mathrm{nmol}$ of coenzyme reduced per $\mathrm{mg}$ of protein per min). However, characteristic electrophoretic mobilities of these enzymes permitted the rapid delineation of most of the species (Table 2) $(22,24)$. For example, the malate dehydrogenase mobilities of $B$. oulorum strains were similar and could be readily distinguished from the malate dehydrogenase mobilities of the other species examined (Table 2).

Strains of $B$. oulorum contained both non-hydroxylated and 3-hydroxylated long-chain fatty acids. The non-hydroxylated fatty acids were primarily of the straight-chain saturated, iso- and anteiso-methyl branched-chain types, with 12-methyltetradecanoic (anteiso- $\mathrm{C}_{15: 0}$ ) acid constituting the major component (Table 3). The 3-hydroxy acids were composed of straight-chain saturated and iso-methyl branched types, with 3-hydroxy-hexadecanoic (3-OH- $\left.\mathrm{C}_{16: 0}\right)$ and 3-hydroxy-15-methylhexadecanoic (3-OH-iso- $\left.\mathrm{C}_{17: 0}\right)$ acids predominating. The long-chain fatty acid composition of $B$. oulorum is consistent with that of other Bacteroides species (20) but does not delineate clearly the former from other oral Bacteroides species (viz., B. buccalis, B. denticola, $B$. oralis, and $B$. pentosaceus).

All of the test strains possessed menaquinones (vitamin $\mathrm{K}_{2}$ ) as their sole respiratory quinones. The quantitative menaquinone profiles are shown in Table 4. Strains of $B$. oulorum were readily distinguished from all of the other oral Bacteroides species examined because they possessed unsaturated menaquinones with 10 isoprene units (MK-10) as the major component (ca. 80\%) (Table 4). B. oralis contained MK-13, B. buccalis contained MK-13 and MK-12, B. denticola contained MK-11 and MK-12, B. pentosaceus con-

TABLE 2. Electrophoretic mobilities of malate dehydrogenase and glutamate dehydrogenase and major end products of metabolism of $B$. oulorum and related taxa

\begin{tabular}{|c|c|c|c|}
\hline \multirow[b]{2}{*}{ Strain } & \multicolumn{2}{|c|}{ Relative mobility in Cellogel $(\mathrm{cm})^{a}$} & \multirow{2}{*}{$\begin{array}{l}\text { Major acid } \\
\text { end } \\
\text { products }^{b}\end{array}$} \\
\hline & $\begin{array}{l}\text { Malate dehy- } \\
\text { drogenase }\end{array}$ & $\begin{array}{l}\text { Glutamate de- } \\
\text { hydrogenase }\end{array}$ & \\
\hline \multicolumn{4}{|l|}{ B. buccalis } \\
\hline NCDO $2354^{\mathrm{T}}$ & 5.3 & 4.2 & $\mathrm{~A}, \mathrm{~S}, \mathrm{iV}$ \\
\hline VPI 8906D & 5.3 & 4.1 & $\mathrm{~A}, \mathrm{~S}, \mathrm{iV}$ \\
\hline \multicolumn{4}{|l|}{ B. oulorum } \\
\hline WPH $179^{\mathrm{T}}$ & 3.0 & $\mathrm{NT}^{d}$ & $\mathrm{~A}, \mathrm{~S}$ \\
\hline RS14 & 2.9 & NT & $\mathrm{A}, \mathrm{S}$ \\
\hline RS20 & 3.1 & NT & $\mathrm{A}, \mathrm{S}$ \\
\hline \multicolumn{4}{|l|}{ B. denticola } \\
\hline NCDO $2352^{\mathrm{T}}$ & 4.2 & 3.4 & $\mathrm{~A}, \mathrm{~S}$ \\
\hline 1221 & 4.1 & 3.4 & $\mathrm{~A}, \mathrm{~S}$ \\
\hline $\begin{array}{l}\text { B. oralis ATCC } \\
33269^{\mathrm{T}}\end{array}$ & 4.1 & 5.2 & $\mathrm{~A}, \mathrm{~S}$ \\
\hline \multicolumn{4}{|l|}{ B. pentosaceus } \\
\hline NCDO $2353^{\mathrm{T}}$ & 3.9 & 4.8 & $\mathrm{~A}, \mathrm{~S}$ \\
\hline J1 & 3.9 & 4.7 & $\mathrm{~A}, \mathrm{~S}$ \\
\hline WPH 61 & 3.7 & 4.8 & $\mathrm{~A}, \mathrm{~S}$ \\
\hline $\begin{array}{l}\text { B. veroralis ATCC } \\
33779^{\mathrm{T}}\end{array}$ & 5.1 & 4.1 & $\mathrm{~A}, \mathrm{~S}$ \\
\hline
\end{tabular}

${ }^{a}$ All mobilities were measured relative to the enzyme of Bacteroides intermedius strain T588.

${ }^{b} \mathrm{~A}$, Acetic acid; S, succinic acid; iV, isovaleric acid. Information in part from references 7,19 , and 24 .

' Glutamate dehydrogenase is nicotinamide adenine dinucleotide dependent (22).

${ }^{d}$ NT, Not tested. 
TABLE 4. Menaquinone compositions of B. oulorum and related taxa

\begin{tabular}{|c|c|c|c|c|c|c|}
\hline \multirow[t]{2}{*}{ Strain } & \multicolumn{6}{|c|}{$\begin{array}{c}\% \text { Composition of the following menaquinone } \\
\text { prenologs: }:^{a}\end{array}$} \\
\hline & MK-9 & MK-10 & MK-11 & MK-12 & MK-13 & MK-14 \\
\hline \multicolumn{7}{|l|}{ B. oulorum } \\
\hline WPH $179^{\mathrm{T}}$ & 3.5 & 80.0 & 16.5 & $-b$ & - & - \\
\hline RS14 & 3.5 & 82.5 & 14.0 & - & - & - \\
\hline RS20 & 4.0 & 78.0 & 18.0 & - & - & - \\
\hline $\begin{array}{l}\text { B. denticola NCDO } \\
2426^{\mathrm{T}}\end{array}$ & 0.5 & 8.5 & 61.0 & 28.0 & 2.0 & - \\
\hline $\begin{array}{l}\text { B. oralis ATCC } \\
33269^{\mathrm{T}}\end{array}$ & - & - & 4.0 & 10.0 & 68.0 & 18.0 \\
\hline \multicolumn{7}{|l|}{ B. pentosaceus } \\
\hline NCDO $2353^{\mathrm{T}}$ & - & - & 8.5 & 44.0 & 45.0 & 2.5 \\
\hline J1 & - & - & 6.5 & 44.5 & 46.5 & 2.5 \\
\hline $\begin{array}{l}\text { B. veroralis ATCC } \\
33779^{\mathrm{T}}\end{array}$ & 1.0 & 35.0 & 60.0 & 4.0 & - & - \\
\hline
\end{tabular}

${ }^{a}$ The $m / z$ values of $\mathrm{M}^{+}$for the menaquinone prenologs were as follows: MK-9, 784; MK-10, 852; MK-11, 920; MK-12, 988; MK-13, 1,056; and MK-14, 1,124 .

${ }^{b}-$, Not present.

tained MK-12, and B. veroralis contained MK-11 and MK-10 (Table 4). The presence of "species-specific" fingerprints in the taxa described above further emphasize the value of menaquinone analyses in the taxonomy of the genus $\mathrm{BaC}$ teroides $(18,20)$.

The DNA base compositions of the test strains and the results of DNA-DNA hybridization experiments are shown in Table 5. B. oulorum strains possessed a $\mathrm{G}+\mathrm{C}$ content of 45.1 to $46.0 \mathrm{~mol} \%$. These data clearly distinguish $B$. oulorum from $B$. denticola and $B$. pentosaceus, which possess a significantly higher $\mathrm{G}+\mathrm{C}$ range, 50 to $52 \mathrm{~mol} \%$ (Table 5). However, the $\mathrm{G}+\mathrm{C}$ content of $\boldsymbol{B}$. oulorum is similar to that of $B$. buccalis ( 45 to $46 \mathrm{~mol} \%$ ) and that of $B$. oralis ( $44 \mathrm{~mol} \%$ ) (Table 5). The three strains of $B$. oulorum formed a single DNA homology group ( 95 to $103 \%$ homology) quite distinct from representatives of the other species examined $(<30 \%$ homology) (Table 5). These genetic data, in conjunction with biochemical, enzymatic, and menaquinone differences, clearly indicate that $B$. oulorum is a distinct species. A full description of $B$. oulorum (ou.lor.um. Gr. n. oula the gums; N.L. gen. pl. n. oulorum of the gums) is given below.

Description of Bacteroides oulorum sp. nov. (i) Cellular characteristics. Nonmotile, nonsporeforming, gram-negative rods approximately $0.5 \mu \mathrm{m}$ wide by 1.0 to $1.5 \mu \mathrm{m}$ long. Gram stains reveal short rods, which may occur singly, in pairs, or in chains of rods (24).

(ii) Colonies. After 2 days of incubation on EggerthGagnon agar, colonies are approximately $1.0 \mathrm{~mm}$ in diameter, circular, entire, convex, translucent, smooth, and shiny (24). Similar colonial morphology occurs on blood agar plates, but the colonies are low, convex, and opaque.

(iii) Cultural characteristics. Obligately anaerobic. Cells grow well in either prereduced peptone-yeast extract-glucose or BM medium supplemented with hemin and menadione (23). The terminal $\mathrm{pH}$ in glucose-containing broth media is 5.0; the terminal pH in media without glucose is $\mathrm{pH}$ 6.2.

(iv) Biochemical and chemical characteristics. Acid is produced from glucose. fructose, glycogen, inulin, lactose, maltose, mannose, raffinose, starch, and sucrose. Acid is not produced from arabinose, cellobiose, glycerol, mannitol, melezitose, rhamnose, salicin, sorbitol, trehalose, xylan, and xylose. Esculin is hydrolyzed. Gelatin is not hydrolyzed. Indole negative. Major end products of metabolism 
TABLE 5. DNA base compositions and DNA-DNA homologies

\begin{tabular}{|c|c|c|c|c|c|c|c|}
\hline \multirow[b]{2}{*}{ Strain } & \multirow[b]{2}{*}{$\begin{array}{c}G+C \text { content } \\
\text { of DNA } \\
(\mathrm{mol} \%)^{a}\end{array}$} & \multicolumn{6}{|c|}{ \% DNA homology to: } \\
\hline & & $\begin{array}{l}\text { B. denticola } \\
\text { NCDO } \\
2352^{\mathrm{T}}\end{array}$ & $\begin{array}{l}\text { B. buccalis } \\
\text { VPI 8906D }\end{array}$ & $\begin{array}{c}\text { B. oralis } \\
\text { ATCC } \\
33269^{\mathrm{T}}\end{array}$ & $\begin{array}{l}\text { B. veroralis } \\
\text { ATCC } \\
33779^{T}\end{array}$ & $\begin{array}{l}\text { B. pentosaceus } \\
\text { NCDO } 2353^{\mathrm{T}}\end{array}$ & $\begin{array}{l}\text { B. oulorum } \\
\text { WPH } 179^{\mathrm{T}}\end{array}$ \\
\hline \multicolumn{8}{|l|}{ B. denticola } \\
\hline $\begin{array}{l}\text { NCDO } 2352^{\mathrm{T}} \\
1221\end{array}$ & $50-51$ & $89-100$ & $20-38$ & $10-35$ & $10-32$ & $16-32$ & $20-26$ \\
\hline \multicolumn{8}{|l|}{ B. buccalis } \\
\hline $\begin{array}{l}\text { VPI 8906D } \\
\text { NCDO 2354 }\end{array}$ & $45-46$ & $11-15$ & $88-100$ & $26-38$ & 14 & $29-34$ & $21-34$ \\
\hline B. oralis ATCC $33269^{\mathrm{T}}$ & 44 & 29 & 16 & 100 & 30 & 24 & 21 \\
\hline B. veroralis ATCC $33779^{\mathrm{T}}$ & 42 & $\mathrm{NT}^{b}$ & 35 & 33 & 100 & NT & 21 \\
\hline \multicolumn{8}{|l|}{ B. pentosaceus } \\
\hline $\begin{array}{l}\text { J1 } \\
\text { WPH } 61\end{array}$ & $51-52$ & $10-26$ & $11-25$ & $0-23$ & NT & $72-100$ & 20 \\
\hline \multicolumn{8}{|l|}{ B. oulorum } \\
\hline WPH $179^{\mathrm{T}}$ & 45.1 & 25 & 31 & 20 & 31 & 21 & $95-103$ \\
\hline RS14 & 46.0 & NT & NT & NT & NT & NT & $95-103$ \\
\hline RS20 & 45.7 & NT & NT & NT & NT & NT & $95-103$ \\
\hline
\end{tabular}

${ }^{a}$ Information in part from references 7,19 , and 24 .

${ }^{b}$ NT, Not tested.

are acetate and succinate. Malate dehydrogenase and glutamate dehydrogenase are present, whereas glucose-6phosphate dehydrogenase and 6-phosphogluconate dehydrogenase are absent.

Sphingolipids are present. Possesses both non-hydroxylated long-chain fatty acids (ca. 90\%) and 3-hydroxy longchain fatty acids (ca. 10\%). The non-hydroxylated acids are primarily of the straight-chain saturated, iso- and anteisomethyl branched types, with 12-methyltetradecanoic acid constituting the major component. The 3-hydroxy acids are of the straight-chain saturated and iso-methyl branched types, with 3-hydroxy-hexadecanoic and 3-hydroxy-15methylhexadecanoic acids the predominant components. The major respiratory quinones are menaquinones with 10 isoprene units (MK-10). The $\mathrm{G}+\mathrm{C}$ content of the DNA ranges from 45 to $46 \mathrm{~mol} \%$, as determined by the melting temperature method.

(v) Source. Isolated from gingival crevices.

(vi) Type strain. The type strain is WPH 179 (= NCTC 11871).

\section{ACKNOWLEDGMENT}

We are grateful to T. MacAdoo for suggesting the specific epithet.

\section{LITERATURE CITED}

1. Benno, Y., T. Mitsuoka, and S. Shirasaka. 1982. Anaerobic bacteria isolated from abscesses in pigs. Jpn. J. Vet. Sci. 44:309-315.

2. Carlsson, J. 1973. Simplified gas chromatographic procedure for identification of bacterial metabolic products. Appl. Microbiol. 25:287-289

3. Collins, M. D., T. Pirouz, M. Goodfellow, and D. E. Minnikin. 1977. Distribution of menaquinones in actinomycetes and related bacteria. J. Gen. Microbiol. 100:221-230.

4. Collins, M. D., H. N. Shah, A. S. McKee, and R. M. Kroppenstedt. 1982. Chemotaxonomy of the genus Capnocytophaga (Leadbetter, Holt and Socransky). J. Appl. Bacteriol. 52: $410-415$.

5. Holbrook, W. P., and B. I. Duerden. 1974. A comparison of some characteristics of reference strains of Bacteroides oralis with Bacteroides melaninogenicus. Arch. Oral Biol. 19: $1231-1235$.
6. Holbrook, W. P., B. I. Duerden, and A. G. Deacon. 1977. The classification of Bacteroides melaninogenicus and related species. J. Appl. Bacteriol. 43:259-273.

7. Holdeman, L. V., R. W. Kelly, and W. E. C. Moore. 1984 Genus Bacteroides, p. 604-631. In N. R. Kreig and J. G. Holt (ed.), Bergey's manual of systematic bacteriology, vol. 1 . The Williams \& Wilkins Co., Baltimore.

8. Holdeman, L. V., W. E. C. Moore, P. J. Churn, and J. L. Johnson. 1982. Bacteroides oris and Bacteroides buccae, new species from human periodontitis and other human infections. Int. J. Syst. Bacteriol. 32:125-131.

9. Johnson, J. L., C. F. Phelps, C. S. Cummins, J. London, and F. Gasser. 1980. Taxonomy of the Lactobacillus acidophilus group. Int. J. Syst. Bacteriol. 30:53-68.

10. Knivett, V. A., H. N. Shah, A. S. McKee, and J. M. Hardie. 1983. Numerical taxonomy of some non-saccharolytic and saccharolytic Bacteroides species. J. Appl. Bacteriol. 55:71-80.

11. Kornman, K. S., and S. C. Holt. 1981. Physiological and ultrastructural characterization of a new Bacteroides species $(B$. capillus) isolated from severe localized periodontitis. J. Periodontal Res. 16:542-555.

12. Marmur, J. 1961. A procedure for the isolation of deoxyribonucleic acid from micro-organisms. J. Mol. Biol. 3:208-218.

13. Marmur, J., and P. Doty. 1962. Determination of the base composition of deoxyribonucleic acid from its thermal denaturation temperature. J. Mol. Biol. 5:109-118.

14. Mitsuoka, T., T. Sega, and S. Yamamoto. 1965. Eine verbesserte Methodik der qualitativen und quantitativen Analyse der Darmflora von Mensen und Tieren. Zentralbl. Bakteriol. Parasitenkd. Infektionskr. Hyg. Abt. 1 Orig. Reihe A 195:445-469.

15. Reid, M. S., and R. L. Bieleski. 1968. A simple apparatus for vertical flat-sheet polyacrylamide gel electrophoresis. Anal Biochem. 22:374-381.

16. Rottem, S., and S. Razin. 1967. Electrophoretic patterns of membrane proteins of Mycoplasma. J. Bacteriol. 94:350-364.

17. Saito, H., and K. Miura. 1963. Preparation of transforming deoxyribonucleic acid by phenol treatment. Biochim. Biophys. Acta 72:642-644.

18. Shah, H. N., and M. D. Collins. 1980. Fatty acid and isoprenoid quinone composition in the classification of Bacteroides melaninogenicus and related taxa. J. Appl. Bacteriol. 48:75-87.

19. Shah, H. N., and M. D. Collins. 1981. Bacteroides buccalis, sp. nov., Bacteroides denticola, sp. nov., and Bacteroides pentosaceus, sp. nov., new species of the genus Bacteroides from the oral cavity. Zentralbl. Bakteriol. Parasitenkd. Infektionskr. Hyg. Abt. 1 Orig. Reihe C 2:235-241. 
20. Shah, H. N., and M. D. Collins. 1983. Genus Bacteroides. A chemotaxonomical perspective. J. Appl. Bacteriol. 55:403-416.

21. Shah, H. N., T. J. M. van Steenbergen, J. M. Hardie, and J. de Graaff. 1982. DNA base composition, DNA-DNA reassociation and isoelectric focusing of proteins of strains designated $\mathrm{Bac}$ teroides oralis. FEMS Microbiol. Lett. 13:125-130.

22. Shah, H. N., and R. A. D. Williams. 1982. Dehydrogenase patterns in the taxonomy of Bacteroides. J. Gen. Microbiol.
128:2955-2965.

23. Shah, H. N., R. A. D. Williams, G. H. Bowden, and J. M. Hardie. 1976. Comparison of the biochemical properties of Bacteroides melaninogenicus from human dental plaque and other sites. J. Appl. Bacteriol. 41:473-492.

24. Watabe, J., Y. Benno, and T. Mitsuoka. 1983. Taxonomic study of Bacteroides oralis and related organisms and proposal of Bacteroides veroralis sp. nov. Int. J. Syst. Bacteriol. 33:57-64. 